\title{
Optimizing the Role of Implementers to Increase Indonesian Sports Performance at the International Level
}

\author{
Musa Anthony Siregar ${ }^{1}$, Isnu Harjo Prayitno ${ }^{2}$, Atma Suganda ${ }^{3}$ \\ \{manthonysiregar@gmail.com ${ }^{1}$, isnuhp@gmail.com ${ }^{2}$, atmasuganda7@gmail.com ${ }^{3}$ \} \\ ${ }^{1,2,3}$ Doctoral Program Studies of Postgraduate Faculty of Law Jayabaya University, Indonesia
}

\begin{abstract}
In accordance with Indonesian Act No. 3 of 2005 concerning the National Sports System, the scope of sport includes educational sports activities, recreational sports, and performance sports. Achievement sports are carried out through a process of coaching and developing in a planned, tiered, and sustainable manner with the support of sports science and technology. Achievement sports activities as the spearhead are carried out by their respective sports branches supported by the Government in accordance with the National Sports System law as a regulator, facilitator and implementer of these activities. The Government as the executive power holder should still limit its role as regulator and facilitator. While the role of executor should be carried out by an institution known as the Indonesian National Sports Committee (KONI), which carries out in the sense of organizing sports activities in accordance with the regulations outlined by the Government with all its support including its facilities. In order to achieve a proud achievement at the International level for this reason, it is necessary to revise the current National Sports System law.
\end{abstract}

Keywords: Law; Sports; International Achievement

\section{Introduction}

Concern for sporting achievements in Indonesia is an important element to improve performance at the international level. Currently seen by the non-optimal role of the implementers, where Act No. 3 of 2005 concerning the National Sports System exist at the time. It does not spell out the role of regulators and the roles that carry it out clearly, decisively, efficiently, and beneficially according to the needs of the current development of the sporting situation in Indonesia. It is time to take strategic steps to optimize their respective roles, where the Government must remain focused as a regulator and non-Government Organizations as implementers. Optimization of each role must be carried out immediately through corrective steps in the field of regulation namely revising Act No. 3 of 2005 concerning the National Sports System, to support the success of Indonesian sports at the international level. The rules of the game that are supportive and clear are the keys to the success of Indonesian sports achievements.

The revision of regulations that reflect clear assignment of duties, functions and authority is time to do and becomes important homework in order to unify determination and purpose. Eliminate counter productive regulations that cause disharmony. By making revisions to these regulations by stating clearly and decisively in the form of a description of the Government's role. As a regulator and the role of the Actor carrying out sports activities in turn through clear authority and support. So now it's time for Indonesia to focus on working quickly going forward to achieve proudly achievements in the international world.The Achievements made in the international world are a pride for a nation and furthermore have an impact on diplomatic recognition [1]. In other words providing political benefits at home and abroad. An international sport activities in the form of the highest multi-event is the Olympics is the dream of every athlete, to be able to participate and play a role through their participation in it. The country certainly has its own pride when it can send its athletes to compete and even win numbers that are contested. It is a matter of 
pride when in the Olympics the national anthem can be played and the national flag can be hoisted. For this reason, it is necessary for the participation of all parties involved, both the Government and Non-Governmental Organizations, in realizing the optimization of the Implementer's role through the revision of Act No. 3/2005 concerning the National Sports System.

\section{Method}

In doing this article using a normative juridical approach method where the legal material used will be analyzed qualitatively and interpretatively, as primary legal material obtained from legislation such as Act No. 3 of 2005 concerning the National Sports System. Then secondary legal materials are obtained from law books, research results from literature and cases and seminars on law and sports. While tertiary legal material is obtained from the legal dictionary and an explanation of the laws and regulations. All materials in supporting the role of executors to improve Indonesian sporting achievements at the international level, through the revision of Act No. 3 of 2005 concerning the National Sports System.

\section{Result and Discussion}

In answering how to optimize the role of the executor to be able to improve Indonesia's sporting achievements at the international level through the revision of Act No. 3 of 2005 on the National Sports System. It is necessary to understand that it is a pride of a nation to have the opportunity to fly a national flag and sing the national anthem at the awards ceremony in the form of gold medals in international championships, both in the form of single events and multi-events obtained from sports achievements. The progress of a nation's sports achievements is obtained from a coaching system that starts from supporting regulations, the willingness, and harmony to do it consistently. In carrying out regulations with adequate facilities, the role of the executor is very important in creating a comprehensive and efficient guidance system. For this reason, the optimization of the role of the executor will greatly support the success of achievement through appropriate regulations in this case through reviewing and making revisions needed to create harmonization of the parties involved by improving the duties, functions and authorities that exist, especially in Government organizations namely the Ministry of Youth and Sports and 2 (two) sports organizations namely the Indonesian National Sports Committee (KONI) and the Indonesian Olympic Committee (KOI) currently in accordance with Act No. 3 of 2005 concerning the National Sports System.

\subsection{The Executor Holds an Important Role}

As one of the important organs in running the wheels of sports activities, it is necessary to pay close attention to the conditions that exist at this time. Where it is necessary to arrange the regulation of the sports system needed to support the process of good coaching and improving the achievements of athletes. Sports achievements in Indonesia in the last few decades tend to be stagnant, except when Indonesia is the host of regional sports in Southeast Asia and Asia. Then observing these achievements as well as following the development of increasingly advanced times. It is time Act No. 3 of 2005 about the National Sports System was revised to adjust to improve the performance of Indonesian sports in the International arena.

[2] Through Article 13 paragraph (1) of Act No. 3 of 2005 concerning the National Sports System, the Government has the authority to regulate, foster, develop, execute, and oversee the implementation of sports nationally. So with the word "execute", then [3] The Government issued Presidential Regulation (Perpres) No. 95 of 2017 concerning the Development of National Sports Achievement by Government. Practically ended the role of the executor carried out by the Indonesian National Sports Committee (KONI) in carrying out sports coaching, because that role has been taken over by The Ministry of Youth and Sports directly carries out training to the parent of the sports branch, without going through the Indonesian National Sports Committee (KONI). Then the role of the Indonesian National Sports Committee (KONI) now helps in the supervision and mentoring of potential athletes only. While the Government in this case the Ministry of Youth 
and Sports, does not necessarily have sufficient resources to carry out, fostering achievement sports in the country.

Amid the great pandemic of COVID 19 the Indonesian National Sports Committee (KONI) with the limited role, it currently has under the leadership of Mr. Marciano Norman as President, continues to carry out its activities in promoting sports in Indonesia. Such as the inauguration of the Indonesian Archery Union Board (PERPANI) and opening a national working meeting of the Sports Union Center Equestrian Indonesia (PORDASI). Is truly a separate value in an atmosphere that does not support but remains highly committed to carrying out its activities for the development of Indonesian sports. The Indonesian National Sports Committee (KONI) also has a Strategic Plan prepared up to 2023 to make a maximum contribution to the achievement of Indonesian sports achievements on the international stage, which is now the time to train athletes at the train to win stage in each competition [4]. However there are still quite wide obstacles between repositioning the Indonesian National Sports Committee (KONI) as an executor with the conditions that are happening at the moment.

The National Sports System implemented by the House of Representatives of the Republic of Indonesia in 2020. The Government, which should be at the level of policy makers in the form of regulations, now with its role in entering into implementing in carrying out sporting activities, will become a separate obstacle, where as policy makers also act as institutions that carry out these policies. So that the functions of the originator and supervision of a regulation will be mixed with its functions which is also the executor, which in turn is questionable about its optimism in carrying out this role. As an institution the Indonesian National Sports Committee (KONI) is required in carrying out its activities as an executor having high dedication to achieve its aims and objectives.

\subsection{The Need for Revision of the Law on the National Sports System}

With the main role of the Government as the regulator, in charge of preparing the direction to balance the implementation of development through the issuance of regulations, as a regulator the Government provides a basic reference to the community as an instrument to regulate all activities in the implementation of empowerment. The concept of a modern state is the less authority of the government and the greater opportunities and opportunities given by the people and society. While in Act No 3 of 2005 concerning the National Sports System in article 36 paragraph (4) reads, that the national sports committee as referred to in paragraph (1) and paragraph (2) has the task: in letter $\mathrm{c}$ it states that it is carrying out management, guidance, and the development of performance sports based on their authority. And the authority to directly develop, develop and carry out de facto all this time has become the authority of the Indonesian National Sports Committee (KONI) with the parent organization of sports.

In reality, there are several obstacles that occur as follows [5]. 1st (First) Article 13 of Law No. 3/2005 concerning the National Sports System, which states that the role of coaching is in the hands of the Government. The Government has the authority to regulate, foster, develop, implement, and oversee the implementation of sports nationally so with the word "carry out", the government issued Presidential Regulation No. 95 of 2017 concerning Development of National Sports Achievement. With the issuance its regulation practically ended the role of KONI in carrying out sports coaching, because that role had been taken over by the Ministry of Youth and Sports, which directly carried out coaching to the Parent's Sports branch, without going through the Indonesian National Sports Commitee KONI again and the role the Indonesian National Sports Committee (KONI) only helps in the supervision and mentoring of potential athletes.

2nd (second) Article 36 of Act No. 3/2005 concerning the National Sports System which states that the Parent Sports branch organizations as referred to in Article 35 form a national sports committee. Organizing national sports committees as referred to in paragraph (1) is determined by the relevant community in accordance with statutory regulations; the parent organization of sports branches and national sports committees as referred to in paragraph (1) is independent. The word "national sports committee", never meant as the name of an organization namely the Indonesian National Sports Committee (KONI). So it is very possible to form another committee that has the same task as the Indonesian National Sports Committee (KONI), which will lead to more 
complicated problems and complicated in the development of sports achievement in the country, namely the split in the development of sports achievement. As an example of the case that occurred in DKI Jakarta as a rival provincial level national sports committee. The Jakarta Sports Branch Forum emerged which rivaled the Indonesian National Sports Commitee DKI Jakarta and in the case in BAORI, the DKI Jakarta Sports Branch Forum actually won its claim over the Indonesian National Sports Commitee DKI Jakarta. But finally, the Provincial Government of DKI Jakarta through the Department of Youth and Sports of the Province of DKI Jakarta took direct control of performance sports in the Province of DKI Jakarta.

3rd (third), Article 44 of Law No. 3 of 2005 concerning the National Sports System which states clearly the name of the Indonesian Olympic Committee (KOI), which is unlike the previous article 36 does not explicitly mention the name of the Indonesian National Sports Committee (KONI). It is only mentioned as the national sports committee word phrase "in lowercase", but in Article 44 it is stated explicitly the name of the Indonesian Olympic Committee (KOI) "in capital letters". Even though it is very clear the role of the Indonesian Olympic Committee (KOI) in paragraphs (1) and (2) tasked with organizing and including Indonesian contingents in multi-event international level championships, including: Sea Games, Asian Games and the Olympics and other multi-event international event activities. The Indonesian Olympic Committee (KOI) promotes and maintains Indonesia's interests, as well as gaining public support for participating in the Olympic Games, the Asian Games, the South East Asian Games, and other international sports weeks. The Indonesian Olympic Committee works in accordance with International Olympic should work according to the rules set by the international olympic committee by not conducting inauguration of several sports in Indonesia. The inauguration in accordance with Article 36 of Act No. 3 of 2005 states: coaching and coordination are carried out by the Indonesian National Sports Committee (KONI).

4th (forth), Article 69 of Act No. 3 of 2005 concerning the National Sports System states that funding of sports is a joint responsibility between the government, regional government and the community. The government and regional governments must allocate the sports budget, through the state revenue and expenditure budget, and the regional revenue and expenditure budget in accordance Article 71 of Act No. 3 of 2005. Its regulation states that the management of sports funds is based on the principles of justice, efficiency, transparency and accountability public, and sports funds allocated from the Government and regional governments can be provided in the form of grants in accordance with statutory regulations. Sports funding is a joint responsibility making the obligations of the government, regional government and the community unclear, resulting in mutual responsibility. With regard to this article, even though the budget for the development and provision of facilities and infrastructure is the government's obligation for the individual or people they protect. While sports activities are one of the basic rights, the rights of individuals, society and the people of Indonesia. Sports funds allocated by the government in the form of grants leave problems of abuse at the center and in the regions, so the allocation of sports funds needs to be budgeted in other forms and channeled directly to the Indonesian National Sports Committee (KONI).

5th (Fifth), Article 88 of Act No. 3 of 2005 concerning the National Sports System states that the resolution of sports disputes, is sought through deliberations and consensus conducted by the parent organization of sports branches.In this case deliberation and consensus as referred to in paragraph (1) is not reached, dispute resolution can be taken through abritase and alternative dispute resolution in accordance with statutory regulations. If the dispute resolution as referred to in paragraph (2) is not reached, the dispute resolution can be carried out through a court in accordance with its jurisdiction. In paragraph (2) Arbitration which is not explicitly mentioned results in several arbitrations, such as those under the Indonesian National Sports Committee (KONI), namely the Indonesian Sports Arbitration Board (BAORI) and under the Indonesian Olympic Committee (KOI), namely the Indonesian Sports Arbitration Board (BAKI). That will at least have an impact of dualism in the arbitration settlement which will not end in settlement. Furthermore, in paragraph (3) which states that the Arbitration decision cannot be reached, then it can be resolved in a court of law which will add to the lengthy resolution of a protracted problem, bearing in mind that there will be an appeal, cassation, and prolonged review, thus disrupting the fostering of sporting achievement. 


\subsection{Comparison of the Role of Implementers in Several Other Countries}

Along with the rapid development and progress of the world of technology and transportation, this has been pioneered by developed countries, especially in the field of sports. It is necessary to quickly make comparisons by examining the sports system carried out by developed countries that can be considered for study or in transfer so that what is possible can be applied in Indonesia. A number of developed countries in the world of sports have different legal systems and different conditions of the people, but can change the pattern of society, so that there are things that can be learned [6] and which will be applied later to change attitute or behavior and coaching behavior for the development of our sports system [7].

Some foreign countries that will be included as a comparison in international multi-event sports activities that can serve as benchmarks for the advancement of Indonesian sports include: Australia, China and Singapore. Australia as a neighboring country of Indonesia but has a remarkable achievement with a relatively short time can build its sports system and skyrocketed as one of the countries with a gold medal contributor which has significant progress in the Olympics. China because of its very large population meanwhile while Indonesia is the largest country number 4 (four) in the world besides China noted a great progress and leap in medal acquisition as one of the most giant get a medal at the Olympics while Singapore because as a fellow country Asean and as the country closest to Indonesia.

The Grand National Sports Development Strategy 2014-2024 of the Indonesian National Sports Committee (KONI) states, that the following organizational sports systems are: 1) The State of Australia, the law adheres to Common Law / Anglo Saxon ideology. The organizational system in the Australian state has the Australian Sport Commission (ASC) which is responsible to the Minister of Sports and the Australian Parliament, financial sources supported by ASC, the legal basis is national sports policy. As stated in the National Sport and Active Recreation Policy Framework (NSARPF) implemented by The Committee of Australian Sport and Recreation Officials (CASRO). ASC itself provides specialized sports services such as: High Performance Coaching, Sport Science, Sport Management, Facility Management, Education and Resources, Participation Development, and Delivery of Funding Programs to the National Sporting Organization. While the Australian Institute of Sport (AIS) spearheaded the strategy in increasing the achievements of Australian sports on the world stage. Australia also has the Australian Olympic Committee (AOC), an organization whose job is to promote, protect and carry out Olympic activities in Australia. However, the Australian Sport Commission (ASC) is actively launching an improvement program.

In 1989, the ASC launched the "Going for Gold" program as the main focus of improving the achievements of leading athletes towards the Olympics. Only a handful of sports were made excellent at the 1980 Olympics in Moscow, Russia. Australia ranked 15th (fifteen) position with 2 gold medals. Australia participated in the 1984 Olympic Games in Los Angeles, United States with four gold medals and ranked 14th (fourteen). In 1988 when participating in the Olympic Games in Seoul, South Korea, Australia ranked 15th (fifteen) and 3 gold then again appearing, at the 1992 Olympics in Barcelona, Spain. Australia succeeded in returning to 10th position with 7 gold medals. After that, taking part in the 1996 Atlanta Olympic Games in the United States, Australia ranked 7th with 9 gold medals. In 2000 following the Olympics in Sydney, Australia recorded a progress achievement again after successfully ranked 4th with 16 achievements. In 2004 at the Olympic Games in Athens, Australia returned to the 4th place with four gold medals. Then in the Beijing Olympics in China in 2008 Australia ranked 6 (six) and won 14 medals, in 2012 at the olympiade in London, England Australia ranked 8th by winning 8 gold medals. Then the last in 2016 followed the olympiade at Rio De Janeiro Brazil ranks 10 (ten) with 8 gold medals. 


\section{Australia's achievements in the Olympics}

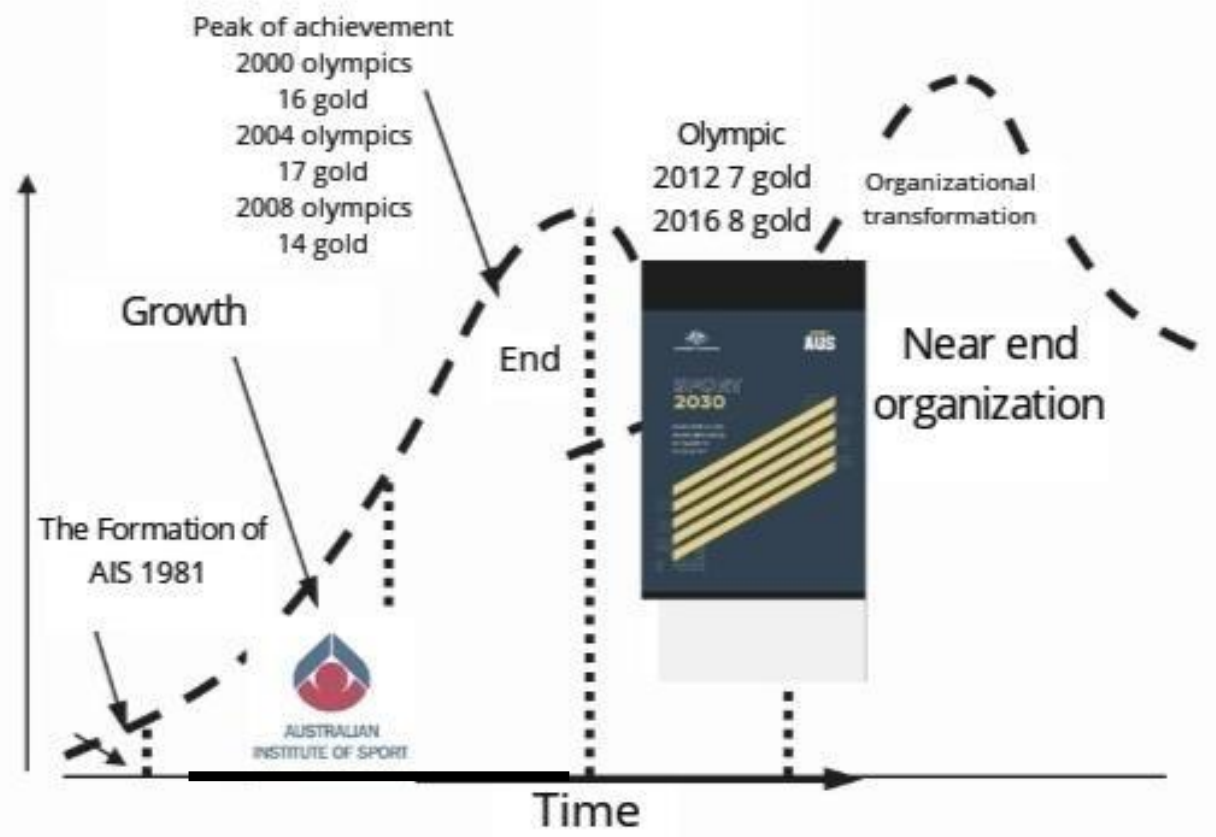

Figure 1. Graphic Australia's Achievements in the Olympics

2) The State of China, has its own legal system which gives much freedom to the autonomy of the area to play an important role, control is preferably politically lawless [8]. Barrie Houtlien and Mick Green in their book Comparative Elite Sport Development System, Structure and Public Policy [9] stated that the Chinese sports organization system under the Ministry of Sports and the Chinese Sports Committee. Chinese pretensions were obtained through the slogan "Juguo Tizhi" which is "the support of all elements of the nation for the sports system elite". It states that the central and regional governments must utilize their authority to channel financial and human resources throughout the country to support elite sports for the glory of the nation. A distinctive feature of Juguo Tizhi is its centralized administration and management system and it only serves to improve the success of the elite sport branches through a special training and voting system. The central government strongly supports the slogan financially owned by the Chinese government. In the beginning the training was carried out following the way of the people's army education namely rigorous training, discipline like in actual combat. In the course of the training method they became "not afraid of suffering,difficulty, and injury". Afterwards every athlete and official apply an attitude in his training to always be under pressure and even officials consider it as a threat to put a sword on their neck in trying to reach the medal target.

In the achievements at the Chinese Olympics again participated in the 1984 Olympic Games in Los Angeles, the United States with 15 gold medals and was ranked 4th after being inactive for 32 years. In 1988, when participating in the Olympic Games in Seoul, South Korea, China fell one place to number 5 (five). Then again appearing at the 1992 Olympics in Barcelona, Spain, China managed to return to position 4 (four) with 16 gold medals. After participating in the 1996 Atlanta Olympics in the United States, China maintained its position 4 (four) with 16 gold medals. In 2000 he joined the Olympic Games in Sydney, Australia. China recorded a progress achievement again after successfully ranked third (three) with 28 gold medals a proud achievement. In 2004 at the Olympic Games in Athens, Greece, China again made an achievement by ranking second (two) and winning 32 gold medals. A proud achievement and now makes China the fastest country to 
achieve extraordinary achievements. Then in the Beijing Olympics in China in 2008 managed to occupy the top of the number 1 (one) and won 51 gold medals. In 2012 at the Olympic Games in London, England, he won 38 gold medals with rank 2. Then the last in 2016 took part in the Olympic Games in Rio De Janeiro, Brazil was ranked 3 (three) with 26 gold medals.

3) The State of Singapore with the Common Law / Anglo Saxon legal system. Singapore's organizational system has the Ministry of Sports Affairs or the so-called Singapore Sport Council (SSC) which is responsible for providing integrated sports facilities. That not only meet the needs of sports programs for all but also meet the standards of sporting achievement. Besides certainly supporting in terms of financial, especially for athletes who have been classified as getting financial support through credit card facilities, that show the government's great attention towards the athletes. Another support carried out by the Government is the program to culture sports for the people of Singapore. So that a Sports Culture Committee is formed to ensure the development of sports culture in Singapore and its athletes to be able to compete with world champions. This is done to change the paradigm in Singaporean society whose parents object to children the children pursue the field of sports. Government then Singapore also has the National Olympic Council of Singapore or what is called the Singapore National Olympic Council (SNOC) which helps and is side by side with the Government.

The Singapore Government's results were seen at the 2016 Olympics in Rio Janeiro Brazil, where their swimmer Josep Schooling won the gold medal in the $100 \mathrm{~m}$ butterfly men's style with a time of 50.39 seconds. Breaking the previous record of 50.58 seconds on behalf of Michael of the United States, other world swimming champions making him as the first swimmer from the Southeast Asian country to win the gold medal for the number. While at the same time pocketing Rp. 9.8 billion as a gold medalist from his country. In addition, Singapore also prepares swimming athletes to train in the United States to face the 2021 Olympics later in Tokyo, Japan. The young athletes are also separated from their obligations to join the conscription program in their country. The young athletes are also separated from their obligations to join the conscription program in their country which accommodates and gives more attention to their athletes through their accommodative legal system. [10].

4) The State of Indonesia, the law of which embraces the concept of Civil Law / Continental Europe. Sports conditions in Indonesia when in general consist of training for athletes carried out by sports branches under the guidance of the Ministry of Youth and Sports (Kemenpora) for 2020, the coaching program carried out states that the Coaching and development of athletes is the responsibility of the Government together with the Regional Government, Society, and sports organizations.

The government through the policy of implementing Athletes Coaching conducts activities to increase National Sports Achievement (PPON) in accordance with Presidential Regulation Number 95 of 2017 concerning National Sports Achievement (PPON). The government carries out athletes through competitions is a strategic step so that parent organizations of sports branches that are given the authority to manage and foster athletes must be able to create athletes who excel in the national arena. Besides that the Ministry of Youth and Sports is currently preparing plans for developing sports achievements in a number of priority sport branches that have the potential to achieve medal at the Olympics. Through the construction of a training camp, with priority in the form of optimizing the construction of national sports centers in Cibubur and Hambalang [11]. Responsibility in the field of Sports Facilities and Infrastructure Development is carried out by the Government, regional government and the community responsible for planning, procurement, utilization, maintenance, and supervision of sports infrastructure.

The government and regional governments guarantee the availability of sports infrastructure in accordance with the standards and needs of the central government and regional governments. The amount and type of sports infrastructure that is built must pay attention to the sporting potential that develops in the local area. Sports infrastructure built in the regions must meet the minimum amount and standards set by the government. Business entities engaged in the construction of housing and settlements are required to provide sports infrastructure as public facilities with standards and needs set by the government, which are then handed over to the regional government as assets belonging to the local government. Everyone is prohibited from negating and / or converting sports infrastructure that has become an asset belonging to the 
government or regional government without the recommendation of the Minister and without permission or approval from the authorities in accordance with statutory regulations. In reality there are still many facilities and infrastructure that are minimal in supporting sports performance and activities, especially at the regional level. This should be evaluated and as an input that sports programs should not be in the form of centralization but rather decentralization as an effort to equalize and better hone the leading branches and potential sports in certain areas.

In the case of implementing sports infrastructure and sports development in Indonesia, the National Development Planning Agency (Bappenas, 2020) also mentioned, among other things, that referring to the provisions of Article 67 of Act No. 3 of 2005, the provision of infrastructure and facilities becomes a joint responsibility between Government, Local Government, Sports and Community Organizations. The pattern of government cooperation with the business world in accordance with Presidential Regulation (Perpres) No. 38 of 2005 concerning Government Cooperation with Business Entities (KPBU) is alternative in overcoming funding limitations in the provision of sports infrastructure and facilities. The maintenance of infrastructure and facilities that have been available and meet standardization needs to be done regularly.

Conditions of Sports Coaching in Education Units through Sports Special Schools (SKO) and Public Schools Sports coaching at SKO organized by the Ministry of Education and Culture, is not in line with Indonesia's sporting achievement goals. Because that the sports branches are fostered too much and are not focused on the Olympic sport branches. Then the athletes who are fostered are not channeled to be fostered as elite athletes or their training has been interrupted, nor is there a special curriculum and comprehensive standardization covering recruitment, training, and Sports Special Schools (SKO) student competition. School Operational Assistance (BOS) funds for those who are still the same as public schools others. For sports competitions in public schools have not been implemented to support the achievement of sports goals. Such as the National Student Sports Olympic (O2SN) activities carried out in stages starting from the district / city but the sports that are contested are not in line with young age competitions at regional and international levels, such as Asean School Games, Youth Olympic Games.The schedule of the implementation of competitions in the education unit is still not well scheduled (has not adjusted the calendar of young sport events in regional and international).

Throughout the history of the Olympics, Indonesia only won medals at 3 sports are badminton, archery and weightlifting. Indonesia first followed the Olympics in Helsinki, Finland 1952. Since 1952 Indonesia has always participated in the Olympics except the 1964 Tokyo Olympics and the 1980 Moscow Olympics which only consistently won Olympic medals in badminton and weightlifting. Things that become homework in Indonesia include the procedures for sports activities, protection of sports players and sources of funding. The sports in Indonesia must become a culture so that the community in carrying out sports activities is a necessity and a part of life. Besides that the activists sports especially athletes who excel deserve to get appreciation so that when they finish fighting to defend the good name and dignity of the Indonesian people in the arena of international sporting events. The National Development Planning Agency (Bappenas) announced the Human Development (Sports) Indicators and Targets and Strategic Policy Directions (Bappenas, 2020), [12] among others about cultural development and improvement of sporting achievements at regional and international levels. Among others includes strengthening and structuring sports regulations, developing sports culture through families, educational units and the community, including recreational sports, traditional sports and special services as well as educational sports.

The structuring of a sport coaching system in stages and continuously, especially through the synergy of sports coaching in educational units, with achievement sports, based on Olympic sports. The regional potential supported by the application of sport science, sports statistics and remuneration systems and awards, structuring on sports institutions to improve sports performance. There is an increase in the availability of international standard sports personnel and an increase in international standard sports facilities and sports facilities that are disabled-friendly, in addition to developing the role of the business community in facilitation, financing, and the sports industry for 2024 by $40 \%$. Indonesia's position in the 2018 Asian Games was ranked 4th which was upgraded in 2022 to rank 5. For the Asian Para Games which ranked 5th then in the last year for 2022 to become fifth or sixth at least, then the number of gold medals at the Olympic 
Games; in Brazil 2016 get 1 gold, and the target for 2024 is 3 gold. And the number of gold medals at the Paraolympic Games which is currently 0, the target for 2024 is 3 gold.

While the mechanism of financial assistance carried out by the Government in this case the Ministry of Finance of the Republic of Indonesia [13] provides assistance to sports players as follows (Ministry of Finance, 2020). Among others, that other aid disbursements that have the characteristics of Government Assistance determined by users of the Budget (Budget Users/PA) in the form of money can be done simultaneously or in stages. Then the determination of disbursements in a manner at the same time or gradually determined by the Budget User Authority (Budget Users/PA) by considering the amount of funds and time of implementation of activities. In disbursing other aid funds that have the characteristics of Government Assistance determined by the Budget User in the form of money given to individuals carried out simultaneously based on Decree. Then the disbursement of other aid funds that have the characteristics of Government Assistance determined by Budget Users given to Community Groups and Government Institutions or Non-Government Organizations can be done at once or in stages based on Decree and cooperation agreement between the beneficiary and the Committing Officer (Commitment Making Official/PPK).

Furthermore, the cooperation agreement carried out includes among other things that the rights and obligations of both parties. Amount of assistance provided, distribution procedures and conditions, a statement of the ability of recipients of Government Assistance to use assistance in accordance with the agreed plan. Statement of the ability of recipients of Government Assistance to deposit the remaining funds that are not used to the State Treasury, sanctions, periodic submission of reports on the use of funds to PPK. Then submission of accountability reports to PPK after work is completed or at the end of the fiscal year.

Descriptions of sporting achievements that were participated in and achieved by Indonesia in the Sea Games, Asian Games and the Olympics multi-event activities [14]:

\section{Indonesia's achievements in the Olympics}

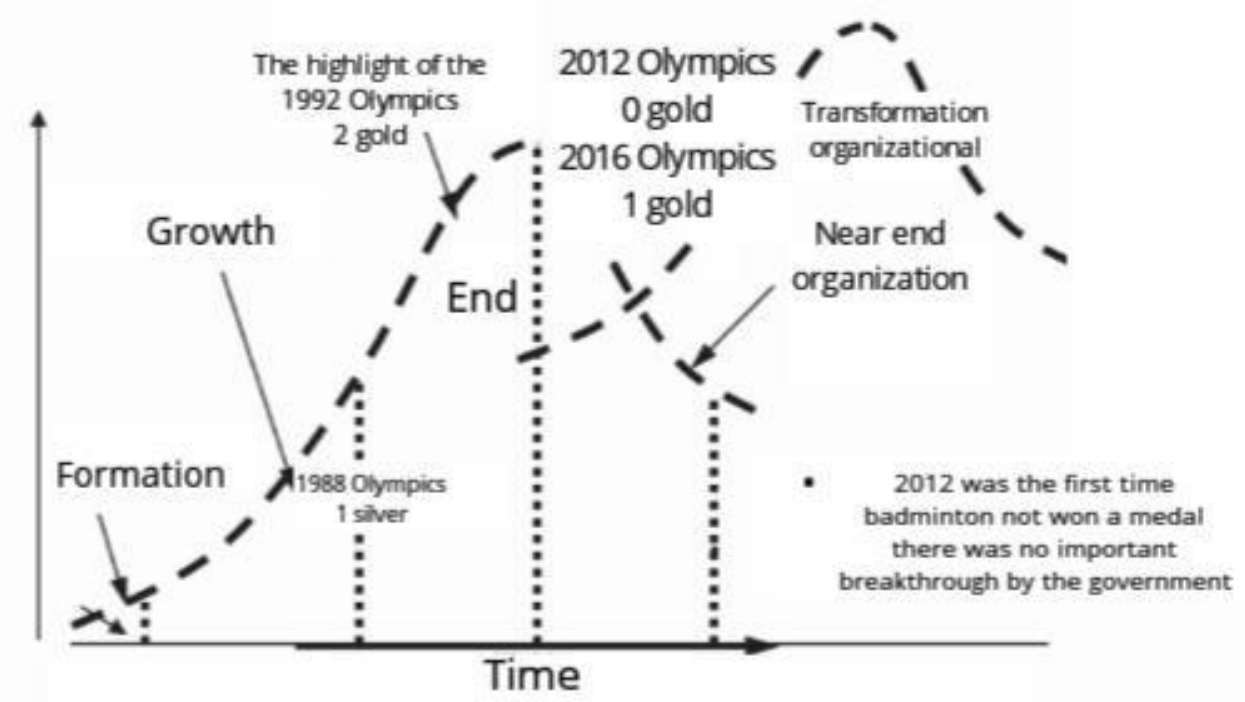

Figure 2. Graphic Indonesian Development Fluctuations at Olympics 


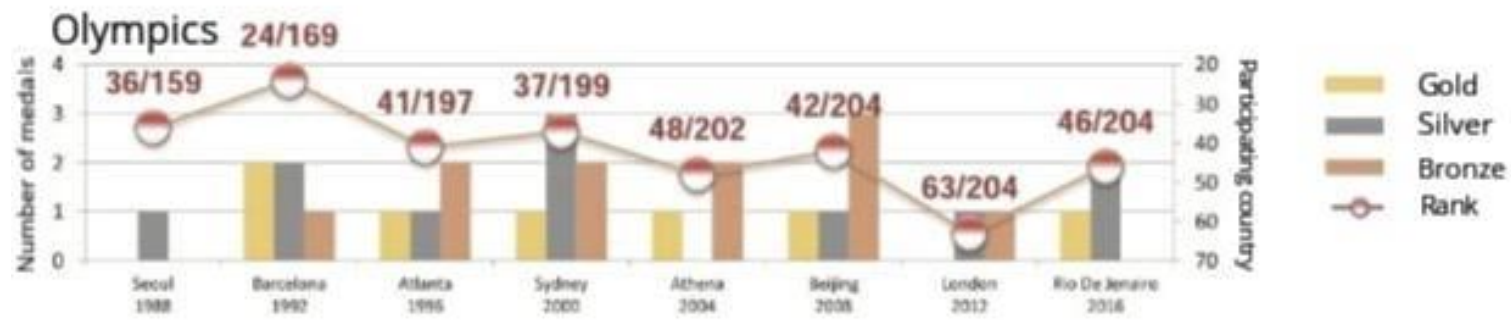

Figure 3. Graphic Indonesian Sports Achievement at Olympics

\section{ASIAN GAMES}

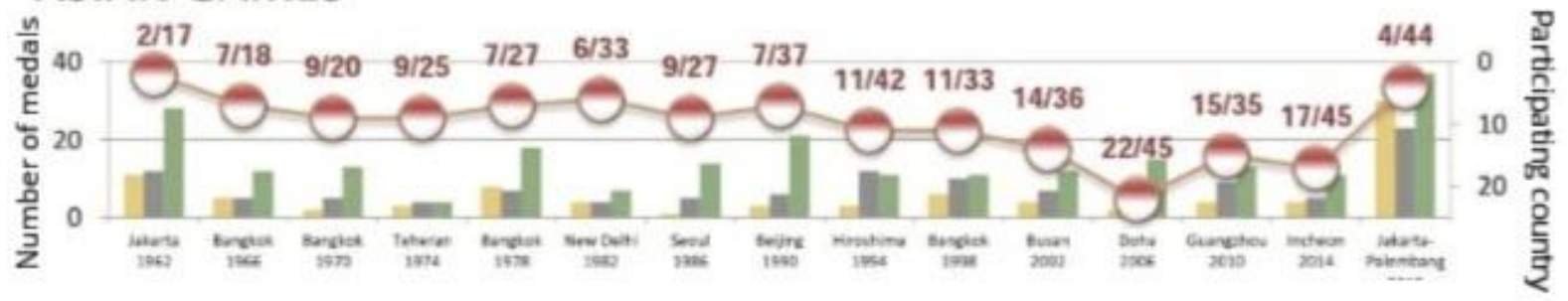

Figure 4. Graphic Indonesian Sports Achievement at ASIAN GAMES

\begin{tabular}{|c|c|c|c|c|c|}
\hline Rank & NOC & & & & (8) \\
\hline 1 & & China & 132 & 92 & 65 \\
\hline 2 & & Japan & 75 & 56 & 74 \\
\hline 3 & $: 0$ & Republic of Korea & 49 & 58 & 70 \\
\hline 4 & & Indonesia & 31 & 24 & 43 \\
\hline 5 & 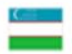 & Uzbekistan & 21 & 24 & 25 \\
\hline 6 & $\div$ & Iran & 20 & 20 & 22 \\
\hline 7 & (2) & Chinese Taipei & 17 & 19 & 31 \\
\hline 8 & 6 & India & 15 & 24 & 30 \\
\hline 9 & 9 & Kazakhtan & 15 & 17 & 44 \\
\hline 10 & $\underline{\underline{\theta}}$ & DPR Korea & 12 & 12 & 13 \\
\hline 11 & & Bahrain & 12 & 7 & 7 \\
\hline 12 & & Thailand & 11 & 16 & 46 \\
\hline 13 & \& & Hongkong & 8 & 18 & 20 \\
\hline 14 & ब्: & Malaysia & 7 & 13 & 16 \\
\hline
\end{tabular}

Figure 5. Indonesian Sports Achievement at ASIAN GAMES 


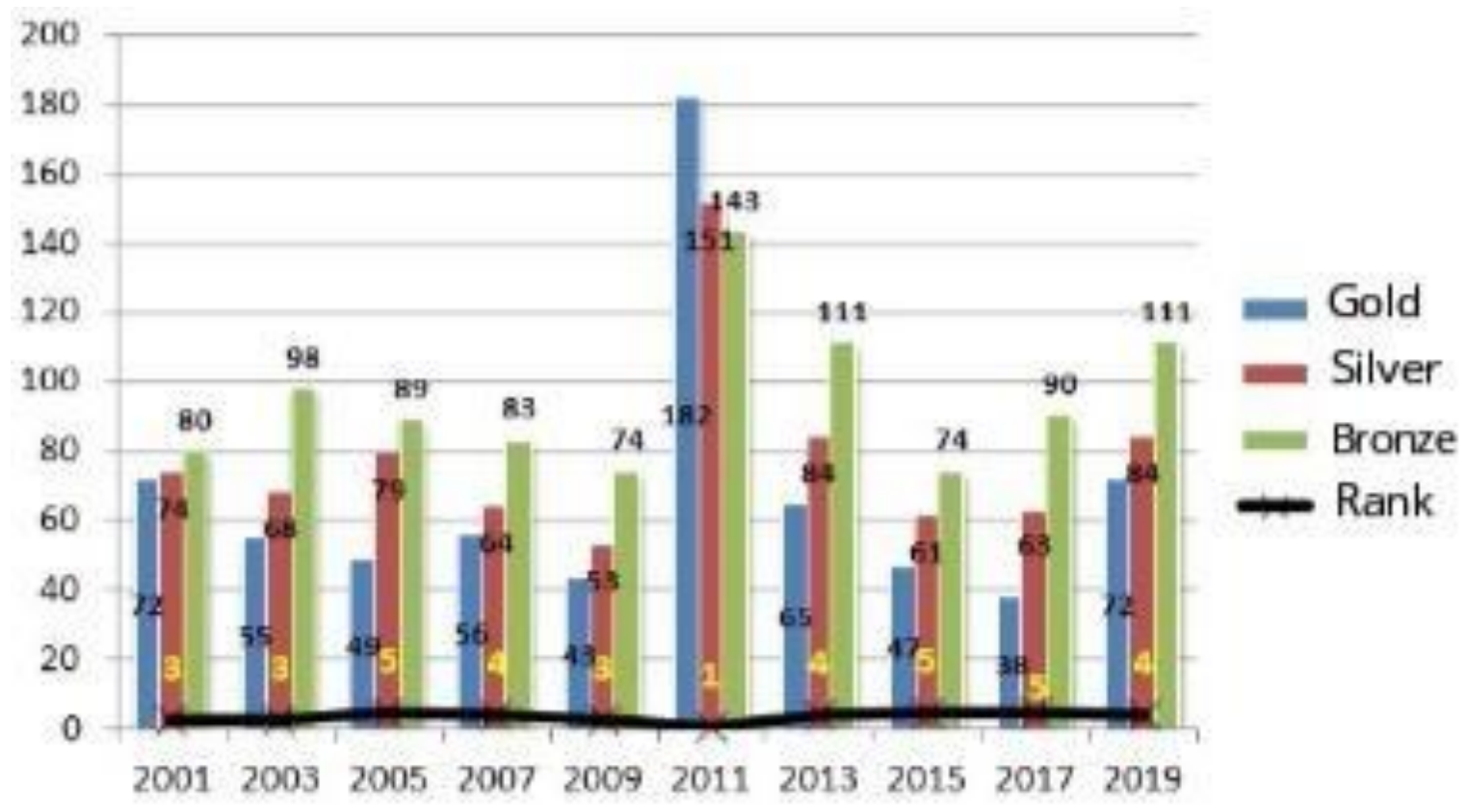

Figure 6. Graphic Indonesian Sports Achievement at SEA GAMES

The comparison obtained from Australia, China, Singapore and Indonesia is as follows:

1) The legal system of the countries influencing the development of their athletes, such as Indonesia, is a country that adopts the concept of Civil law, Australia and Singapore adheres to the common law conception, while China has its own legal system that focuses on the influence of regional autonomy by assuming politics as a controller stronger than law each country's legal system has advantages and disadvantages of each in accordance with the conditions of their country which certainly has an impact on the regulations made and their implementation;

2) The sports system in each country will determine success in supporting sports such as Indonesia currently governed by Government organizations, namely the Ministry of Sports and Youth, and Non-Government Organizations, namely the Indonesian National Sports Committee (KONI) and the Committee The Indonesian Olympics (KOI). While the sports system in China by the Chinese Ministry of Sports, the sports system in Australia has the Australian Sport Commission (ASC) which is responsible to the Minister of Sports and the Australian Parliament and Australian Olympic Committe (AOC), The sports system in Singapore is managed by the Government under the Ministry of Sports Affairs or who referred to as the Singapore Sport Council (SSC) and Non-Government Organization, the Singapore National Olympic Council or the so-called Singapore National Olympic Committee (SNOC). In general, sports organizations in the world are divided into 4 (four) forms. [15];

a) National Organizing Committee (NOC) as the only sports organization with the status of a Government Organization (GO) with the example of China through the Ministry of Sports of China ex officio President of the NOC - China / other Socialist;

b) There are 2 (two) Sports Organizations namely as the National Sport Council (NSC) as Government Organization (GO) in this case the Minister of Sports ex-officio President of the National Sport Committee (NSC) and the National Organizing Committee (NOC) as independent NGO's as in countries of Malaysia (National Sport Committee and Olympic Council of Malaysia), United Kingdom (Sport England and British Olympic Association), Australia (Australian Sport Commission and Australian Olympic Committee), Singapore (Singapore Sport Council and Singapore Olympic);

c) Countries that were originally are two separate NGOs National Sport Committee (NSC) and National Olympic Committee (NOC) which then finally rejoined a country, the Netherlands: the Nederlands Olympisch Committee (NOC) Nederlandse Sport Federatie (NSO), Germany: 2006 
which was once composed of the Deutsher Sport Bund and the Nationales Olympischer Committee Deutschland united under the name Deutsher Olympischer Sport Bund, South Korean country with the Korean Olympic Committee and the Korea Sports Council joined in 2009 under the name Korea Olympic Committee;

d) National Organizing Committee (NOC) as the only sports organization with the status of Non-Government Organization (NGO) with the example of the United States of America with the United States Olympic Committee (USOC);

3) In terms of achievement, China has experienced rapid progress since re-participation in the United States in 1984 with 15 gold and 4th positions and had occupied the first position with 51 gold at the 2008 Olympics in Beijing, most recently at the 2016 Olympics in Rio de Janeiro Brazil occupying the third position with 26 golds. Australia experienced rapid progress in Moscow Uni Soviet in 1980 with 2 gold and 15th positions. Then 4th position with 16 gold in Sydney, Australia and last 2016 in Rio De Janerio with 8th gold, 10th position. Singapore as a neighboring country despite having a small population but trying to get up with sources their support and try to perform optimally even though it was only in 2016 at the Olympics in Rio de Janeiro Brazil get their first gold medal.

4) Financial support, the Chinese state is fully supported by their country with a single sport system under Government control, in Australia getting full support from the Government through the Australian Sport Commission (ASC) and Singapore fully supported by their Government Singapore Sport Council (SSC), while Indonesia until now still relies on full support from the Government.

\begin{tabular}{|c|c|c|c|c|c|}
\hline No & Article & Goverment & KOI & KONI & $\begin{array}{l}\text { Requirement } \\
\text { (indonesia) }\end{array}$ \\
\hline 1. & $\begin{array}{c}\text { Article } 13 \text { of Act No. 3/2005 } \\
\text { (The Government has the } \\
\text { authority to regulate, foster, } \\
\text { develop, implement, and } \\
\text { oversee) }\end{array}$ & Full authority & N/A & $\begin{array}{l}\text { As advisor to } \\
\text { Government }\end{array}$ & $\begin{array}{l}\text { KONI has Authority as } \\
\text { Implementer/Executor } \\
\text { and report to } \\
\text { Goverment }\end{array}$ \\
\hline 2. & $\begin{array}{c}\text { Article } 36 \text { of Act No. } 3 / 2005 \\
\text { (The word "national sports } \\
\text { committee", never meant as the } \\
\text { name of an organization) }\end{array}$ & $N / A$ & N/A & $\begin{array}{l}\text { Stated as "national } \\
\text { sport committe" }\end{array}$ & $\begin{array}{l}\text { KONI Clearly Stated } \\
\text { "Indonesian National } \\
\text { Sport Committe" } \\
\text { (KONI) }\end{array}$ \\
\hline 3. & $\begin{array}{c}\text { Article } 44 \text { of Act No. } 3 / 2005 \\
\text { (stated explicitly the name of } \\
\text { the Indonesian Olympic } \\
\text { Committee (KOI)) }\end{array}$ & N/A & Clearly Stated KOI & As a duplicate of $\mathrm{KONI}$ & $\begin{array}{l}\text { To be one Organization } \\
\text { (KONI) }\end{array}$ \\
\hline 4. & $\begin{array}{l}\text { Article } 69 \text { of Act No. 3/2005 } \\
\text { (Funding of Sports) }\end{array}$ & $\begin{array}{c}0.056 \%(\mathrm{APBN} \\
2017)\end{array}$ & N/A & N/A & $\begin{array}{c}(1-2) \% \text { from } \\
\text { Government/ APBN }\end{array}$ \\
\hline 5. & $\begin{array}{l}\text { Article } 88 \text { of Act No. 3/2005 } \\
\text { (Resolution of Sport Dispute) }\end{array}$ & N/A & Has BAKI & Has BAORI & $\begin{array}{c}\text { To be one Arbitration } \\
\text { Institution }\end{array}$ \\
\hline
\end{tabular}

Figure 7. Artilcle Revision Table 


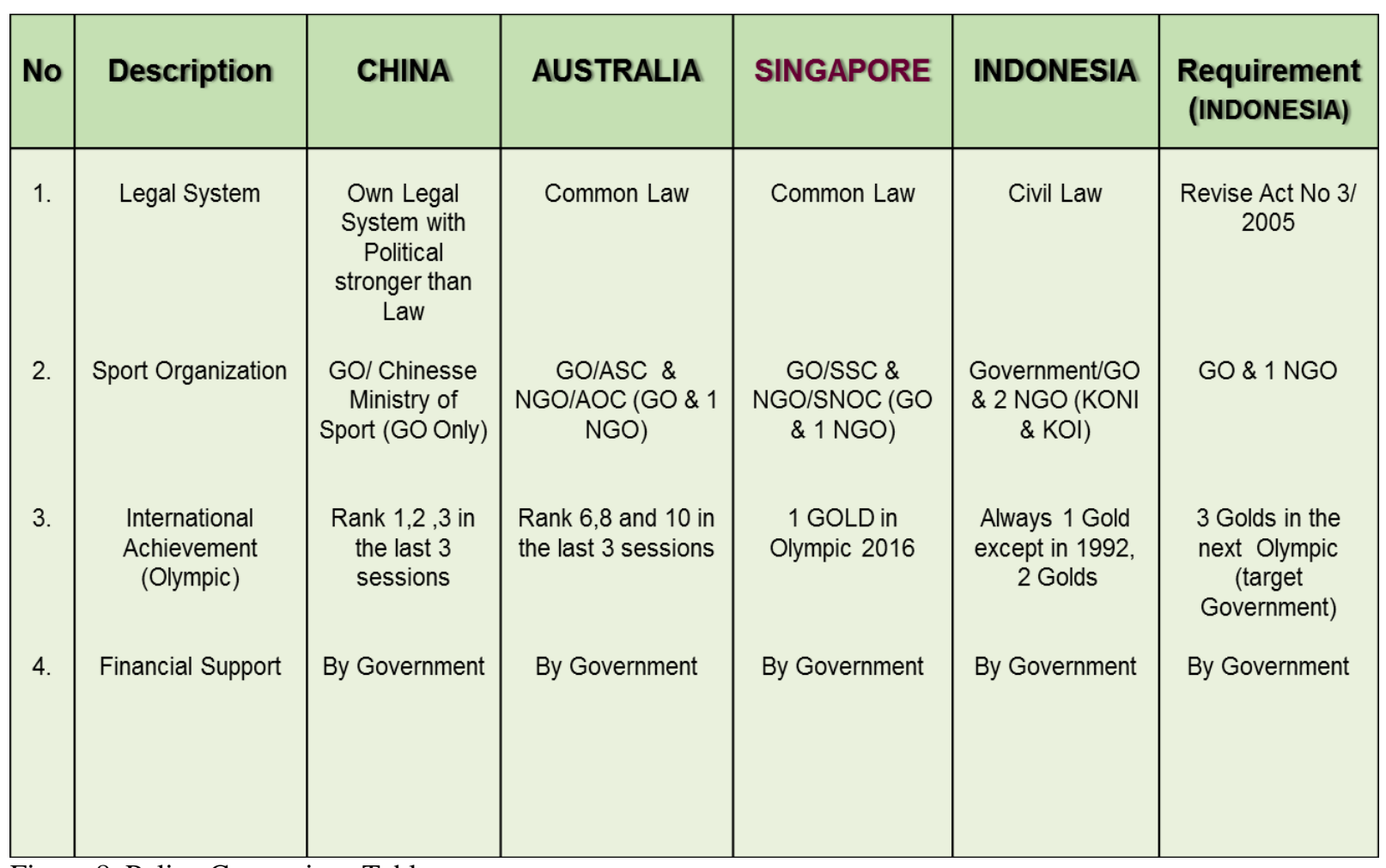

Figure 8. Policy Comparison Table

\section{Conclusion}

In order to optimize the role of Indonesian National Sports Commitee KONI) as an Executor, it is necessary to take strategic steps to achieve optimal goals. The role of the executor needs to be optimized by clarifying his position in carrying out the duties. Functions and authority by appointing and returning the Indonesian National Sports Commitee (KONI) as the only Non Government Organization (NGO) and function of the Government which acts as a regulator and facilitator only. Revise Act No. 3/2005 concerning the National Sports System by amending Articles 13, 36, 44, 69 and 88 of Act No. 3/2005 concerning the National Sports System mentioning the role of the executive in Non-Government Organizations namely the Indonesian National Sports Commitee (KONI). Explicitly mentions the name of the Indonesian National Sports Commitee (KONI). Uniting the Indonesian Olympic Committee (KOI) into the Indonesian National Sports Commitee (KONI). Later its function could be in coaching and exiting for the Olympics. Funding by emphasizing the government allocates (1-2)\% for the development of Indonesian sports achievements. Only 1 (one) sports dispute resolution agency in Indonesia.The need for the Government's role in improving the performance of Indonesian sports that adheres to the civil law system like improvements in supporting regulations, facilitations and funding. The right guidance by conducting comprehensive comparative studies to several countries that are progressing rapidly in their achievements, by taking the right benefits and can be applied in Indonesia.

\section{Acknowledgment}

The author would like to express special thanks to Rector of Jayabaya University and Head of Doctoral Program Studies of Postgraduate Faculty of Law Jayabaya University for providing facilities to join the Conference of the International IC ILS 2020 UNNES. 


\section{References}

[1] Indonesian National Sports Commitee, Grand National Sports Achievement Development Strategy Year 2014-2024,Jakarta : Gramedia, 2014. pp. 1-2. (2014).

[2] Republic of Indonesia, Act Number 3 Year 2005, National Sports System ,Article 13. (2005)

[3] Presidential Regulation (PERPRES) Number 95 Year 2017 Improvement of .National Sports Achievement, (2019).

[4] Indonesian National Sports Commitee Guidelines for the Development of Long-Term Achievement Athlete, Jakarta: Publica Institute, (2019).

[5] Indonesian National Sports Commitee, Material for Exposure to National Work Programs.(2020).

[6] Fuady, Munir, The Big Theories in Law (Grand Theory), Jakarta : Prenadamedia Group, pp. 248-250. (2013).

[7] Erwin, Muhammad, Philosophy of Law, Depok: Publisher PT Rajagrafindo Persada, pp.128-129. (2018).

[8] Bogdan Michael, Comparative Law, Bandung : Nusa Media, pp 281-282. (2018).

[9] Houtlihan Barrie \& Green Mick, Comparative Elite Sport Development System, Structure and Public Policy, UK, : Published by Elsevier Ltd, 2008. pp 34,67,77. (2008).

[10] Cruz de Peter, Comparison of Legal Systems, Common Law, Civil Law, and Sosialist law, Bandung : Nusa Media, pp 175-176. (2016).

[11] Bakti Candra, The Concept of the National Youth Sports Development Plan, Deputi IV Minister of Youth and Sport, in National Work Meeting Seminar ITA,(2020).

[12] Woro, Srihastuti, Internal Sports Policy in RPJMN Year 2020-2024, Director of Family, Woman, Child, Youth and Sports, Miniistry of PPN/ Bappenas, in National Work Meeting Seminar ITA, (2020).

[13] Sugiarto, Mechanism for the Implementation of the Government Assistance Budget to the Ministry of Finance (PMK No 168/PMK.05/2015), in National Work Meeting Seminar ITA, (2020).

[14] National Sports Commitee of Indonesia, Graphics Material for Exposure to National Work Programs, (2020).

[15]Sri Sudono Sumarto, Input for Improvement of the Republic of Indonesia, Act Number 3 Year 2005, National Sports System. (2020). 